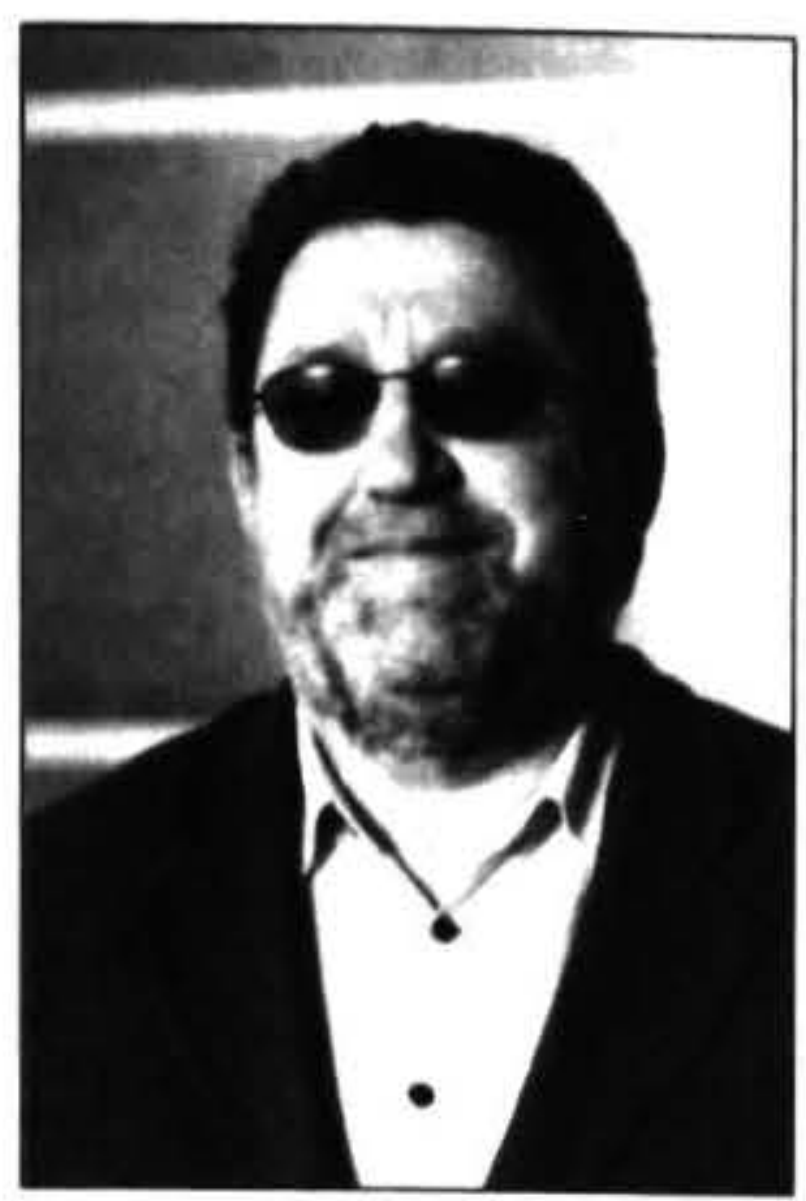

\title{
MIGRATION AND \\ POPULATION AGING: THE GLOBAL CHALLENGE
}

\author{
Brian Easton
}

Independent Scholar

\begin{abstract}
This paper argues that not only do aging populations face the need for sufficient workers to provide them with public pensions, the elderly also need workers to service their needs. The likely source of these relatively unskilled workers is from migration from poorer countries. thus linking labour markets in a globalised world much more than might be expected from the experience of the Twentieth Century. These migrants will be ethnically different from the destinations populations, as occurred in the Nineteenth Century. The most import research challenge is to get an indication of the magnitude of the flows and therefore the degree of resulting ethnic heterogeneity:
\end{abstract}

Aging is a global phenomenon, that is it exists in many parts of the globe. This paper argues it is also a globalisation phenomenon, that is it involves the increasing interaction between national and regional economies. My Marsden funded book, The Globalisation of Nations, to be published next year. argues that this integration is driven by the falling cost of distance, which means that today information is readily available just about anywhere, that technology is internationally mobile but local conditions have to be receptive for it, that capital is similarly mobile while, of course, land is immobile.

The pattern for labour is more complicated. It could be said that it was more mobile in the nineteenth century, when globalisation began, than it is today. Then there were very few artificial restrictions on labour mobility, although the possibility of international migration to the New World countries was only really available to Europeans. As soon as Asians showed any substantial propensity to migrate - towards the end of the nineteenth century - restrictions were placed on them. Moreover, the costs of distance for migrants were not insignificant. So the first migrants to the New World came from more affluent Western Europe and it was only as the living standards of other Europeans rose. that they joined the flood.

The magnitude of the flows were extraordinary. Some 60 million people left Europe in the century after 1820 for the New World of which 36 million went to the United States. In 1820 Europe's population was about 220 million people, rising to 320 million in 1913, so around one in five of the population migrated. Over the same period, the population of the countries they mainly went to - the United State, Canada, Australasia, South Africa, and the Southern American cone - rose almost tenfold from about 14 million to 134 million.
The migrants and their descendants were the main source of this spectacular growth.

Of course, migration has happened since the beginning of human history. This time it was (largely) not coerced slaves and convicts - or indentured (contracted) labour. While some migrants were primarily refugees of war, terror, religious persecution and famine, much was 'free' labour. It driven by greater opportunities in the New World compared to those in the Old World, and the increasing affordability of passages and communications home.

Although many of the migrants faced hardship and death, those who survived generally ended up better off than had they stayed at home. Meanwhile those left behind also materially benefited. Had there not been the migration from Europe, the continent might have had an extra 100 million souls by 1913 - probability less, given higher mortality from greater disease, poorer nutrition, and civil disability. Possibly the continental wars would have been earlier and even more horrendous.

Thus the New World contributed to the development of the Old World - by taking surplus population and supplying food and other resources. It was land (and other resources) rich, but it lacked the labour to work them. The (relatively) free flow of labour utilised the land for the rising demand for food in Old World countries.

There was a rising trend of intercontinental migration through the nineteenth century. Typically, 300,000 left Europe for the frontier societies annually from 1850 to $1880 ; 600,000$ in the remainder of the century; $1,300,00$ at the beginning of the Twentieth Century. Numbers fell away after the First World War to below 200,000 in the 1930s. Net international migration to the more developed regions rose from almost nothing in 1950 to around 2.5 million a year in 2000. Even so, in comparison to the more than 700 
per million of the world's population that was migrating each year at the beginning of the Twentieth Century, there was only 300 per million at its end.

The fall-off was the result of restrictions imposed by the destination countries, for the descendants of the earlier migrants had settled in and saw themselves culturally and economically threatened by further arrivals. One of the themes of the book is that the nation state is a relatively recent development - no earlier than the nineteenth century. As it reached maturity it both identified a community self-interest, and gathered the powers to pursue it. One of its greatest powers, even today, is the nation-state determines who are citizens and who may be residents, by controlling entry in its economic and cultural interests.

Thus nation states restrict the migrants by number and also by mix. Where a rich destination is involved. a higher proportion of the migrants are skilled, filling in gaps in the labour force more cheaply than by training. There are still unskilled and refugees, but the restrictions has led to reductions in their importance.

The pattern of migration changed too. These days over 100,000 net people leave annually from each of China. Mexico, Pakistan, India, Iran, Philippines Indonesia and Kazakhstan. Europe is now a destination for migrants rather than a source, although the United States remains the largest single destination.

Curiously, despite in 2000 there being around 2.5 million migrants a year to the more developed regions, the UN projects that the rate will be just under 2 million a year for the next fifty years. Had they continued the trend of the previous 50 years, they would have projected close to 5 million migrants in 2050. The underlying assumptions reflect those of individual countries - often wary of migration for cultural and political reason. But is the UN projection realistic:?

\section{Economic Theory}

An application of economic theory challenges this. One way of interpreting standard international trade theory is that is shows that when labour mobility is limited between economies, some of the loss of economic output from the restricted labour mobility may be regained by trading goods instead. In effect instead of the labour migrating, labour embodied goods do.

Thus one of the justifications for the North American Free Trade Agreement was it would discourage Mexican migration by relocating their potential US jobs south of the border. The apocryphal illustration is of a Mexican who sneaked across the border, lived illegally in the margins of California society, got documentation as the result of an amnesty, to find that following NAFTA the factory where she worked was moved south, because labour was cheaper in Mexico.

As attractive as the economic theory is, it applies only to those jobs and products which are internationally tradeable - goods and those services which can be delivered by telecommunications. They make up less than half of a modern economy, and perhaps nearer a quarter. Land cannot be moved from California to Mexico, so there remain opportunities for Latino workers on American farms. Nor can personal services move far, unless the consumer shifts too. While there is a little of such flexibility, as when Americans retire in Mexico, there remains many low skilled service jobs to the north. Despite creating some jobs south of the Rio, NAFTA has not eliminated opportunities for Latino migrants in America, nor has it staunched the illegal migration.

\section{The Aging of the Rich Countries}

Current international projections suggest that the countries facing serious aging challenges in the first part of the Twenty-first Century are all the Rich Countries, plus China (although increasing longevity and falling fertility will mean some of the current developing countries will face similar challenges later). The projections have roughly the same proportion of the over 80 year olds in rich countries in 2050 (9.6 percent) as there are over 65 s today $(9.9$ percent in 2000). They predict that just over a fifth of the population will be over 65 in 2050, roughly the proportion that is over 55 today.

The figures for the entire world do not shift as much. Its proportion of over $65 \mathrm{~s}$ rises from 6.9 percent to 11.0 percent, and over 80 s from 1.1 percent to 4.1 percent. The aging problem in the next 50 years is mainly in the more developed world. China aside.

In a world in which all commodities are tradeable, one might envisage the elderly building up savings during their working lives and use their accumulated wealth to provide their needs in retirement. But this does not say where the commodities are produced (nor where the savings are invested). It assumes that it does not matter whether the products are produced locally, elsewhere in the nationeconomy or offshore. It assumes that the retired can purchase them from wherever they are produced for their local use.

However, many personal services can only be consumed close to where they are produced. That means that the retired need workers living close to them. When the population is aging, there are relatively fewer local workers. Will there be enough?

A further complication is that in most rich countries the retired depend upon transfers from workers as a part of their retirement consumption. (Even in the US for the poorer retired and medial care for all, together with - more contentiously - the private subsidies to be given to underfunded private superannuation schemes). The problem of the rising ratio of non-workers to workers as the population ages, is a well debated issue. It reinforces the analysis being developed here.

So there is a double squeeze. First, aging means a relative reduction of workers to provide public retirement support. Second the retired are not dependent upon public support, 
there is a relative reduction of workers who can provide the services they require.

Suppose population trends followed the UN projections, in which case the squeeze may be strong. Indeed it may be sufficient to undermine the restricted migration that the UN projections assume if the elderly insist on additional migration to meet their needs. (This assumes that the Japanese ambition to create robots which can replace personal care workers will not be overly successful.)

What happens if instead of migration flattening out, even falling a little, the rising trend of the last fifty years continues, doubling to a net annual flow of about 5 million migrants to the rich world, or about 400 migrants per million - only about half the rate of the peak at the beginning of the twentieth century?

Fortunately, UN population projections can be rejigged to track this migration assumption. If, in addition, we assume that people in rich countries work five years longer than they do today, we find that the non-work to work age group ratio will be much the same in rich countries as it is today. So rich countries can resolve the economics of their aging challenge by migration trends more similar to what has been happening in the past, rather than the official agencies projection (together with slightly longer working lives, but not long enough to reduce total retirement years).

\section{The New Zealand Challenge}

I want to illustrate the general principle by migration from the Pasifika peoples to New Zealand.' The Pacific Islands have a different demographic expectation from aging New Zealand. As a rough approximation, the fertility rate of women in Samoa averages about two daughters per woman, compared with about one daughter in New Zealand. (Samoan women in New Zealand have about $1 \frac{1}{2}$ daughters each. half way between the rate where they come from and where they now live.) This means that while New Zealand will be experiencing an aging population from increased longeivity, Samoa may not, depending on its rate of out-migration.

I am pessimistic of the Islands' ability to survive economically, without contribution of migrants remittances. (Hawaii is the exception.) This suggests that their survival is likely to depend upon outmigration of their youth which lowers population pressure, while the migrants' remittances will support the home economy, as they already do.

What has to be considered is the sort of skills that are required from these migrants. The international preference is for highly skilled migrants, since it is cheaper to import them than to produce the skills locally. However the jobs the elderly need are often relatively low skilled - perhaps illustrated by nurse aids in retirement homes. Pacific Island migrants are attractive for this purpose. Sadly they do not have the opportunities in their home islands to obtain advanced skills. But by coming to New Zealand, their low skills with good character are ideal for the provision of many of the required personal services.

Working in New Zealand generates higher incomes than staying on in the Pacific, although the margin diminishes when remittances and the costs of visiting are deducted. Being in New Zealand may offer them more opportunity for self-improvement and almost certainly there will be greater opportunity for their children.

Why cannot these services be supplied by those already living in New Zealand? First, because of the aging population there is not going to be enough of them. Second, the upskilling of New Zealanders means that they will tend to be over-skilled for these services.

I do not know the magnitudes. My guess is that the Pacific Islands can make a significant contribution to our aging population needs, but they may not be sufficient by themselves, especially if the draw-off is limited so as not to undermine the Pacific Island nations. It may be that New Zealand will have also to draw on migrants from Papua New Guinea and Asia. The next research stage might be to start systematically modelling the magnitudes.

The cultural consequences are not unimportant. New Zealand can probably absorb unlimited quantities of Pasifika peoples, because they are already an integral part of the nation. Unskilled migrants from Melanesia and Asia may provide a bigger cultural challenge.

\section{The Global Migration Challenge}

New Zealand's story is similar to other ageing rich countries. As the age structure transition works its way through, there will be a demand for migrants to provide the services for the elderly, which the local workforce does not. This new migration will on average be less skilled than has been the implicit assumption in the UN projections.

It will also be ethnically different. That was true in the Nineteenth Century, when the descendants of migrants dominated those of the First Peoples in the New World. But with the exceptions of Latinos in the US, the new migrants are unlikely to constitute a major population sub-group in most of the Rich Club - not by 2050 anyway - but they will be changing their new country`s ethnic composition.

The ethnic composition of the international migrants will change. The UN projections may over-estimate the first ranking of Chinese migration, given that China will also be suffering aging, and underestimate Africa as a potential source of migration, given its burgeoning population growth. Of course the composition will vary by destination: Latinos will generally go to the US; East and South Asian to most parts of the world; Africans and West Asians to Europe.

How countries will deal with the economic and ethnic problems will vary. Canada will no doubt celebrate the challenge, while Japan is more closed to the gaijin 
(foreigners). The US with its tradition of migration may be more responsive than Europe whose tradition is of out-migration. An interesting possibility is to be selective by culture. Canada balances its English and French speaking arrivals. If Europe is really concerned about the Moslem intake it may switch to African Christians, who may not fit easily into secular Europe either.

There are various means of reducing migrant's ethnic impact, including temporary work permits and pepperpotting (not allowing the migrants to cluster in neighbourhoods). But they are likely only to delay any cultural impact rather than eliminate it.

So while greater international migration can resolve with a slightly later effective age of retirement - the economic problems posed by the rich world's ageing, it poses a considerable cultural challenge to nation-states predicated on some notion of cultural commonality. Where this paper is innovative is the argument the migrants will have to included relatively unskilled workers in order to supply the personal services to the aged and others.

As a result the magnitude of the international migration in the Twenty-first Century may be greater than current thinking allows. We may be sure that the ethnic composition of each member of the Rich Club will be very different a century on from what it is today. In a way the labour market in the globalised Twenty-first Century may have a labour market more like the Nineteenth Century than like the Twentieth.

\section{Future Research}

More attention needs to be given in population projections to the skill and ethnic composition (and also to the sources of migrants) with the implication may be that in order to avoid the aging crisis both immigration will be larger and more heterogeneous than is currently being contemplated. (Care will also be necessary to see this in a world wide context, since other countries - notably Australia in our region - will be competing for some of the immigrants.) Once some idea of the magnitudes is assessed, thought needs to be given to how these immigrants will settle in New Zealand. Ultimately, this research is for providing a context in which an informed public discussion can take place.

\section{Notes}

1 It is not my intention here to be insensitive to the national and cultural aspirations of the Pasifika and I welcome the rich contribution they already make to New Zealand life. I got thinking about these issues because Samoa is an exemplar in The Globalisation of Nations. It, The Cooks and Nauru are the three Pacific Island exemplars in my next project, a New Economic History of New Zealand - I have a Claude McCarthy Fellowship for 2007 to pursue this task. 